\title{
Lake Orta chemical status 25 years after liming: problems solved and emerging critical issues
}

\author{
Michela ROGORA, " Lyudmila KAMBURSKA, Rosario MOSELLO, Gabriele TARTARI \\ National Research Council, Institute of Ecosystem Study, Largo Tonolli 50, 28922 Verbania Pallanza, Italy \\ *Corresponding author: m.rogora@ise.cnr.it
}

\begin{abstract}
Lake Orta, located in Piedmont, northwestern Italy, has been severely affected by industrial pollution since the 1930s. A successful liming intervention, performed in 1988-1990, returned pH levels in the lake to neutrality, and accelerated the reduction of aqueous trace metal concentrations. In this paper, we present an update knowledge of the chemical status of Lake Orta, focusing on the data collected from 1990 to 2014. In this period we sampled the lake at its deepest point (Qualba station), on a monthly (1990-2000) or seasonal (since 2001) basis. Samples were collected at nine depths through the water column, and analyzed for pH, conductivity, alkalinity, major ions, nutrients, and trace metals. Collectively, these data allowed us to evaluate the long-term response of the lake to the restoration treatment, with particular regard to its acid-base status; they also provided insights into emerging or potential critical issues, including eutrophication and re-suspension of trace metals that still linger in the lake. Furthermore, the evaluation of the present chemical condition of the lake is a precondition for any successive restoration measure, such as fish introduction. The recent data confirmed the lake's water quality has recovered, i.e. returned to a pre-pollution chemical state. Lake water values of pH and concentrations of ammonium, sulphate and base cations have stabilized. Alkalinity and nitrate concentrations are also expected to reach stable level in the next few years. Levels of nitrate, reactive silica, and phosphorus compounds are now regulated by algal uptake, providing indirect evidence of a partial biological recovery. For instance, both the inter-annual average decline and the reappearance of a seasonal signal in silica confirmed the presence of a stable diatom community. The lake is presently oligotrophic, and concentrations of both $N$ and $P$ compounds are steady and low throughout the year. However, a monthly check of nutrient levels of the lake and inflowing waters is recommended. The monitoring of base chemical variables, major ions and trace metals should be maintained to assess the overall status of the ecosystem in response to various drivers, including climate change.
\end{abstract}

Key words: Acidification recovery; long-term trends; monitoring; trace metals; nutrients; LTER.

Received: August 2015. Accepted: November 2015.

\section{INTRODUCTION}

Beginning in 1926, Lake Orta was seriously affected by copper and ammonium sulphate discharge from a rayon factory, and subsequent in-lake oxidation of the ammonium acidified the lake and decimated its food web. The rayon factory (Bemberg) was located on the southern shore of the lake, across from the outflow (Fig. 1). The factory produced rayon using a cupro-ammoniacal method, which required the collection of huge amounts of water. Its subsequent discharge, after industrial processing, polluted the lake with high concentrations of copper and ammonium sulphate, but at different time periods. The first dramatic pollution event was due to copper, probably discharged accidently. Given its phytotoxicity, $\mathrm{Cu}$ pollution led to the virtual disappearance of phytoplankton with a time lag of two years, and with resultant damage to the whole food chain (Monti, 1930; Baldi, 1949). In the 1960s and 1970s, industrial discharges of $\mathrm{Cu}, \mathrm{Cr}, \mathrm{Ni}$ and $\mathrm{Zn}$ from plating factories located in the southern part of the drainage basin constituted a second source of pollution (Bonacina et al., 1973,
1988; Baudo et al., 1989). While the load of copper from the rayon factory decreased after 1958, ammonium was still discharged in amounts of 2000-3000 t N yr${ }^{-1}$ (Bonacina et al., 1986; de Bernardi et al., 1996). The inlake oxidation of ammonium to nitrate progressively depleted the natural alkalinity of the lake, which was originally low because of the watershed's lithology; this caused a progressive decline in $\mathrm{pH}$ in these soft lake waters from 6.7 in 1948 (Baldi, 1949) to minimum values of 3.8-4.0 over the whole water column in 1984 (Mosello et al., 1986; Fig. 2). This constituted severe and biologically damaging acidification.

A recovery plant constructed at the rayon factory began operating in 1981, drastically reducing ammonium and copper load to the lake (Bonacina et al., 1986), and the adoption of a new national law regulating urban and industrial discharges to freshwaters (Italian law n. 319, 10 May 1976) provided the impetus for developing a lakewide recovery plan. To underpin such a plan, an intensive, multi-year study of the lake was initiated in 1984. This study had the aims of quantifying the chemical budget of 


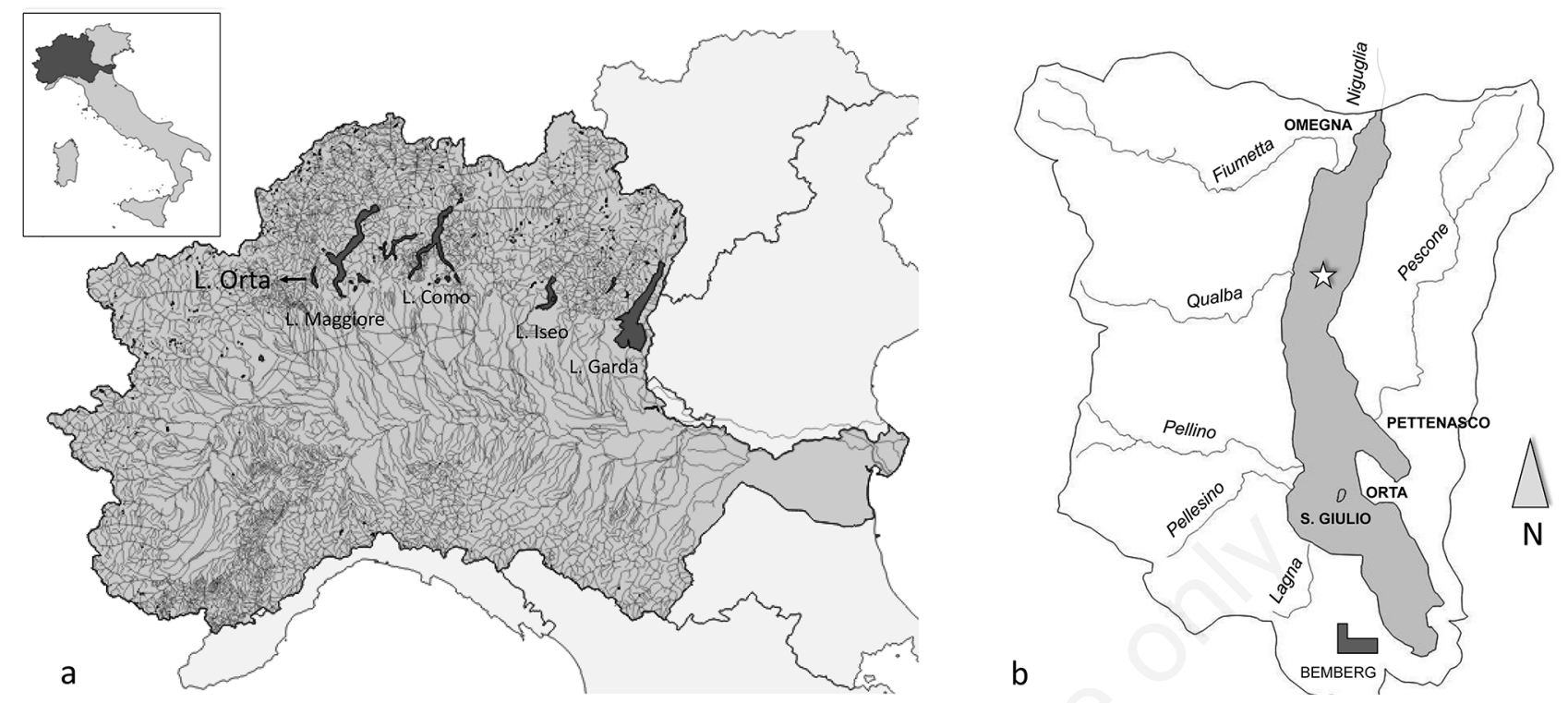

Fig. 1. The location of Lake Orta in Northern Italy, River Po basin (a) and Lake Orta and its catchment (b), with the location of the sampling point (i) and the main tributaries.

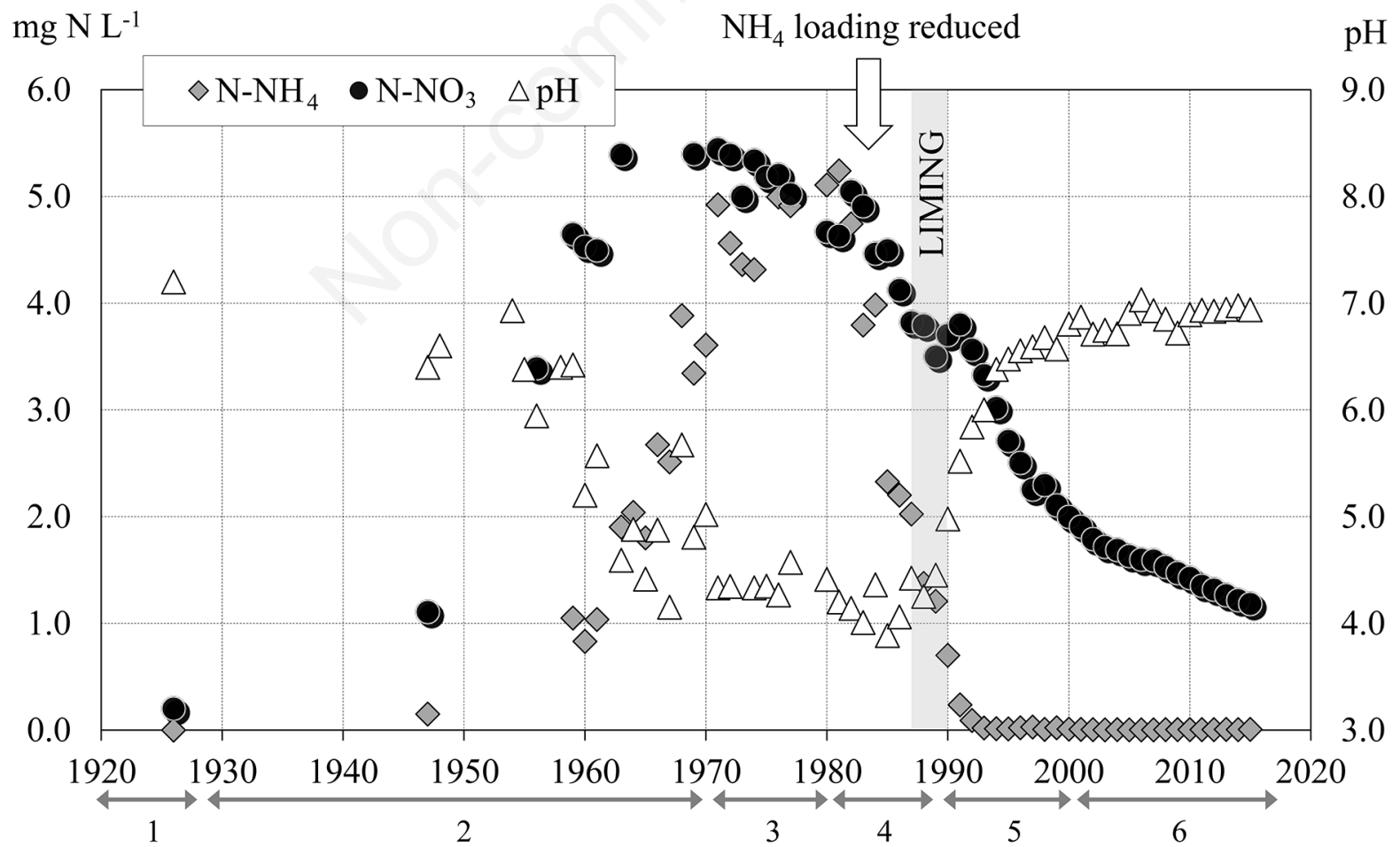

Fig. 2. Long-term trend of $\mathrm{pH}$, ammonium and nitrate concentrations in Lake Orta. Average values along the water column at spring overturn. The grey area highlights liming period. Periods from 1 to 6 as in Tab. 1 . 
the lake, identifying the main sources of pollution, and quantifying the fate, transport and evolution of the main pollutants in the lake (Mosello et al., 1986; Calderoni et al., 1991). The data assembled were used to calibrate an input-output model, which incorporated the effect of the input of alkalinity from the watershed on the acidity of the lake. Use of the model indicated it would take 15-20 years for alkalinity of the lake to reach $0.2 \mathrm{meq} \mathrm{L}^{-1}$ without assistance (Bonacina et al., 1987; Mosello et al., 1991). Hence, in 1986, the Istituto Italiano di Idrobiologia of the National Research Council proposed a liming intervention in the lake (Bonacina et al., 1987) in order to accelerate recovery. The proposal was approved by the Provincial and Regional Administrations and sponsored by the Ministry of the Environment. The project anticipated 18000 tons of $\mathrm{CaCO}_{3}$ was needed to reach a Total Alkalinity (TA) of about $0.05 \mathrm{meq} \mathrm{L}^{-1}$, even after the oxidation of all remaining industrial ammonium in the waters (Calderoni et al., 1992). Funds subsequently acquired supported only a part of the projected need, i.e. enough for an addition of finely powdered natural limestone in an amount equivalent to 10900 tons of pure $\mathrm{CaCO}_{3}$. The lake was limed between May 1989 and June 1990, with a slurry of powdered limestone sprayed on the lake surface from a moving barge. The physical, chemical and biological benefits of the intervention were real, and have been described in several publications (see Bonacina, 2001). The great improvement in water quality also benefitted from more stringent control of the industrial and urban sewage discharge in the watershed, and from the closing of the rayon factory.

We have continued the chemical monitoring of the lake since 1990, using the same sampling and analytical methodologies of the previous period. Sampling frequency was monthly from 1990 to 2000, while four samplings per year were performed since 2001. The main tributaries and the outlet have also been monitored monthly from the early 1980s to 2010, and loads of the main chemical compounds have been calculated on an annual basis. These data permit a longer-term evaluation of both the response of the lake to the restorative interventions, and an assessment of the present state of lake's acid-base and trophic status. This information, coupled with that from the studies about the biological communities (Morabito, 2016; Piscia et al., 2016) contributes to the definition of the lake ecological and chemical status. Furthermore, an in-depth knowledge of the lake chemical and trophic status is a precondition for the planning of any restoration measure, such as fish introduction (Volta et al., 2016).

The objectives of this paper are: i) to evaluate the long-term change in the chemistry of Lake Orta, in response to two classes of drivers: the liming and other pollution-reduction interventions, inputs of nutrients and major ions from the tributaries; ii) to update knowledge of the chemical status of the lake, focusing on the period after the liming, but especially from 2000 to 2015; and iii) to identify emerging, potentially important environmental issues which might require future research and/or management.

\section{METHODS}

Lake Orta is located in the Piedmont Region, northwestern Italy, and is part of the subalpine Lake District, including lakes Maggiore, Como, Iseo and Garda (Fig. 1a). The lake is $143 \mathrm{~m}$ deep and has an area of $18.14 \mathrm{~km}^{2}$; the watershed area is $116 \mathrm{~km}^{2}$. The present mean theoretical water renewal time is 10.7 years. The lake is fed by six main tributaries (Fiumetta, Qualba, Lagna, Pellino, Pellesino, Pescone; Fig. 1b); the outlet, River Niguglia, drains the lake to the north, flowing into Lake Maggiore through rivers Strona and Toce. For more detailed information on the lake's morphometric and hydrological features, see Bonacina (2001).

As in the other deep subalpine lakes, full overturn in Lake Orta normally occurs at the end of January, with the associated homogenization of the chemical variables, but when winters are mild, mixing is incomplete, so that the lake is classified as holo-oligomictic. It is thermally stratified from May to November, with mean depth of the thermocline of about $6.5 \mathrm{~m}$ between August and September (Ambrosetti and Barbanti, 2002). The lake catchment is mainly composed of acid, weathering-resistant rocks, such as gneiss, micashists and granites. As a consequence, the water of Lake Orta originally had a low content of solutes and a limited buffer capacity, with total alkalinity

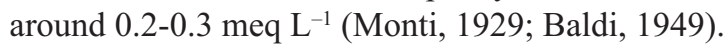

Due to its long-term data series, Lake Orta has been included in Italy's LTER network (Long-Term Ecological Research), as part of the Parent Site IT08 Southern Alpine Lakes (http://www.lteritalia.it/). Water chemistry samples have been collected from the deepest point of the lake (Qualba station, Fig. 1b) since research on the lake began. Samples were collected at nine depths through the water column $(0,10,20,30,50,75,100,120,134 \mathrm{~m})$. Water temperature was measured by means of reversing thermometers connected to the sampling bottle. The laboratory analyses considered $\mathrm{pH}$, conductivity, alkalinity, dissolved oxygen, major ions, nitrogen and phosphorus compounds, reactive silica and trace metals. The main tributaries of the lake and the outlet, River Niguglia, have been sampled monthly from 1984 to 2010, and analysed for the same variables as tracked in the lake, with the exception of dissolved oxygen.

Mean concentrations of the solutes in epilimnion (0$25 \mathrm{~m})$, hypolimnion $(25-143 \mathrm{~m})$ and on the whole water column were calculated as weighted average of concentrations measured at different depths on the volume of the respective water layers. 
To address in a greater detail the issue of trace metals still present in lake water, an in-depth based study was done in 2012-2013. This was part of a joint sampling campaign on lakes Orta, Maggiore and Mergozzo, collecting samples from the water column at the deepest point of each lake in March, July, September and December and analyzing them for $\mathrm{Al}, \mathrm{Cd}, \mathrm{Cr}, \mathrm{Fe}, \mathrm{Mn}, \mathrm{Ni}, \mathrm{Pb}$ and $\mathrm{Zn}$ by ICP-OES.

Since the 1960s, all the chemical analyses have been performed at the hydrochemical laboratory of the CNR ISE in Verbania Pallanza. Details of the analytical methods and the quality assurance/quality control adopted in the laboratory are provided at http://www.idrolab.ise.cnr.it/. Particular attention has been paid to the comparability of the data in time, both through the use of control charts and by performing paired analyses for at least two years when new analytical techniques were being introduced (Tartari et al., 1995).

Because discharge data were not available for the tributaries but only for the outlet, discharges for the inflowing rivers were estimated taking into account the ratio between the area of each river catchment and the area of the whole lake catchment. Annual input and output of the main chemical variables were calculated by multiplying average annual concentrations by the corresponding calculated discharge values.

Lake chemical data collected in the last 15 years were used to update the situation of the lake status with respect to the previous periods. We calculated average values of the main chemical variables during six main periods (Tab. 1), identified as follows: 1) Pre-pollution or reference period, before the onset of the industrial discharge (before 1928); 2) First phase of the industrial pollution, dominated by the discharge of copper and ammonium sulphate (1929-1970); 3) Second phase of the pollution, when industrial effluent from plating factories were added (1971-1980); 4) Third phase, starting with the construction of the recovery plant in 1981, which strongly reduced the ammonium load (1981-1988); 5) The recovery phase, from the liming treatment (1989-1990) till $2000 ; 6)$ The recent period (2001-2014), representative of the present condition of the lake.

\section{RESULTS AND DISCUSSION}

\section{Long-term chemical changes in Lake Orta}

The main periods of Lake Orta chemical evolution

Tab. 1. Water chemistry of Lake Orta in different periods of its evolution (mean values at the spring overturn); periods from 1 to 6 as described in Methods section.

\begin{tabular}{|c|c|c|c|c|c|c|c|c|}
\hline Parameter & Unit & $\begin{array}{c}1 \\
\text { Pre-poll. } \\
\text { before } 1928\end{array}$ & $\begin{array}{c}2 \\
\text { Poll. phase } 1 \\
1929-70\end{array}$ & $\begin{array}{c}3 \\
\text { Poll. phase } 2 \\
1971-80\end{array}$ & $\begin{array}{c}4 \\
\text { Poll. phase } 3 \\
\text { 1981-88 }\end{array}$ & $\begin{array}{c}4 \text { bis } \\
\text { Peak values } \\
\text { March } 1985\end{array}$ & $\begin{array}{c}5 \\
\text { Recovery } \\
1990-2000\end{array}$ & $\begin{array}{c}6 \\
\text { Recent } \\
2001-14\end{array}$ \\
\hline $\mathrm{pH}$ & & 7.2 & 6.5 & 4.7 & 6.2 & 3.9 & 6.9 & 6.9 \\
\hline Cond. $20^{\circ} \mathrm{C}$ & $\mu \mathrm{S} \mathrm{cm}^{-1}$ & - & - & 118 & 126 & 151 & 108 & 102 \\
\hline Total alk. & meq $\mathrm{L}^{-1}$ & 0.25 & - & 0.006 & 0.001 & 0 & 0.11 & 0.26 \\
\hline $\mathrm{SO}_{4}^{--}$ & $\mathrm{mg} \mathrm{L}^{-1}$ & 5.0 & - & 23.7 & 30.8 & 31.4 & 30.9 & 24.2 \\
\hline $\mathrm{N}^{-\mathrm{NO}_{3}^{-}}$ & $\mu \mathrm{g} \mathrm{N} \mathrm{L}^{-1}$ & 100 & 1106 & 4915 & 4206 & 4490 & 2758 & 1512 \\
\hline $\mathrm{Cl}^{-}$ & $\mathrm{mg} \mathrm{L}^{-1}$ & 1.5 & 2.4 & 2.2 & 2.4 & 2.3 & 2.5 & 3.6 \\
\hline $\mathrm{H}^{+}$ & $\mu \mathrm{eq} \mathrm{L}^{-1}$ & 0 & 0.3 & 19.9 & 0.6 & 125.9 & 0.1 & 0.1 \\
\hline $\mathrm{N}-\mathrm{NH}_{4}^{+}$ & $\mu \mathrm{g} \mathrm{N} \mathrm{L}^{-1}$ & 0 & 150 & 3414 & 2484 & 2289 & 46 & 4 \\
\hline $\mathrm{Ca}^{++}$ & $\mathrm{mg} \mathrm{L}^{-1}$ & 4.0 & 5.7 & 5.4 & 7.6 & 6.7 & 13.2 & 12.9 \\
\hline $\mathrm{Mg}^{++}$ & $\mathrm{mg} \mathrm{L}^{-1}$ & 1.0 & - & 1.5 & 1.5 & 1.5 & 1.6 & 1.6 \\
\hline $\mathrm{Na}^{+}$ & $\mathrm{mg} \mathrm{L}^{-1}$ & 2.5 & - & 5.4 & 5.3 & 5.2 & 4.4 & 4.4 \\
\hline $\mathrm{K}^{+}$ & $\mathrm{mg} \mathrm{L}^{-1}$ & 0.7 & - & 1.0 & 1.0 & 1.0 & 1.0 & 1.0 \\
\hline $\mathrm{RSi}$ & $\mathrm{mg} \mathrm{Si} \mathrm{L}^{-1}$ & 2.0 & - & 3.8 & 4.2 & 4.1 & 3.6 & 2.5 \\
\hline $\mathrm{TN}$ & $\mathrm{mg} \mathrm{N} \mathrm{L}^{-1}$ & - & - & - & 6.5 & 7.5 & 3.0 & 1.6 \\
\hline $\mathrm{RP}$ & $\mu \mathrm{g} \mathrm{P} \mathrm{L}^{-1}$ & - & - & 2 & 2 & 1 & 1 & 2 \\
\hline TP & $\mu \mathrm{g} \mathrm{P} \mathrm{L}^{-1}$ & - & - & 7 & 6 & 4 & 5 & 5 \\
\hline $\mathrm{Cu}$ & $\mu \mathrm{g} \mathrm{L}^{-1}$ & - & - & 72 & 37 & 35 & 12 & 2 \\
\hline $\mathrm{Al}$ & $\mu \mathrm{g} \mathrm{L}^{-1}$ & - & - & - & 93 & 75 & 30 & 3 \\
\hline $\mathrm{Zn}$ & $\mu \mathrm{g} \mathrm{L}^{-1}$ & - & - & 102 & 55 & 58 & 30 & 14 \\
\hline $\mathrm{Fe}$ & $\mu \mathrm{g} \mathrm{L}^{-1}$ & - & - & 39 & 87 & 88 & 10 & 2 \\
\hline $\mathrm{Mn}$ & $\mu \mathrm{g} \mathrm{L}^{-1}$ & - & - & - & 111 & 100 & 80 & 2 \\
\hline $\mathrm{Cr}$ & $\mu \mathrm{g} \mathrm{L}^{-1}$ & - & - & 7 & 4 & 5 & 2 & 1 \\
\hline $\mathrm{Ni}$ & $\mu \mathrm{g} \mathrm{L}^{-1}$ & - & - & - & 17 & 20 & 14 & 8 \\
\hline
\end{tabular}


were highlighted in the long-term trend of $\mathrm{pH}$, ammonium and nitrate concentrations recorded in Lake Orta since 1925 at spring overturn (Fig. 2).

The pre-disturbance or natural condition of the lake was characterized by an epilimnetic $\mathrm{pH}$ slightly above 7.0, and almost absence of nitrate and ammonium, as expected and observed in the other subalpine Italian lakes (Monti, 1930). At the end of the 1940s nitrate concentration was already abnormally high (about $1 \mathrm{mg} \mathrm{N} \mathrm{L}^{-1}$ ) because of ammonium oxidation, while water column ammonium level remains negligible. Nitrate continued its increase in the 1960s, and ammonium content in the water also began to increase.

The $\mathrm{pH}$ values ranged between 7.0 and 6.0 in the 1960 s, then began an impressive decrease, reaching values of 4.3 over the whole water column in the 1970s, falling to a minimum of 3.9 in February 1985, over the whole $143 \mathrm{~m}$ water column (Tab. 1). The lake water acidification was correctly interpreted as an effect of the ammonium oxidation (Tonolli and Volleweider, 1961; Vollenweider, 1963), following the reaction:

$$
\mathrm{NH}_{4}^{+}+2 \mathrm{O}_{2} \rightarrow \mathrm{NO}_{3}^{-}+2 \mathrm{H}^{+}+\mathrm{H}_{2} \mathrm{O}
$$

The 1981 reduction of the ammonium load from industrial waste (Bonacina et al., 1986) lowered ammonium concentrations in the lake quickly, while the rate of decrease of nitrate was slower, as the oxidation of lingering ammonium refreshed its supply, with attendant continued production of acidity. Furthermore the buffered water layer epilimnion during thermal stratification became more stable, permitting the establishment of some pioneer forms of plankton (Morabito and Curradi, 1997).

Considering again the whole water mass, while all the added ammonium initially discharged was completely oxidized to nitrate, in the 1960s ammonium started to accumulate in the lake water (Fig. 2), as the amount discharged exceeded the oxidation capacity of the dissolved oxygen. Both ammonium and nitrate reached very high concentrations, up to $5.0-5.5 \mathrm{mg} \mathrm{N} \mathrm{L}^{-1}$ in the $1960 \mathrm{~s}$ and $1970 \mathrm{~s}$ (Fig. 2). In addition to the changes in $\mathrm{N}$ species, sulphate and conductivity also increased, the latter due both to the higher solute concentrations and to the presence of the hydrogen ion, whose specific conductance is higher than that of the other ions.

To provide a more comprehensive view of variations in time of cations and anions (Fig. 3), we calculated prepollution concentrations (before 1927) using the few measurements available (Monti, 1929; 1930; Baldi, 1949; Picotti, 1964) and assuming:

- $\mathrm{Ca} / \mathrm{Mg}$ and $\mathrm{Na} / \mathrm{K}$ ratio equal to the mean values of the tributaries;

- anions concentration equal to cations concentrations;

- values of $\mathrm{Na}, \mathrm{K}$ and $\mathrm{Cl}$ close to the values measured in the 1970s;

- very low nitrate and sulphate concentrations $(0.1 \mathrm{mg}$
$\mathrm{N} \mathrm{L}^{-1}$ and $5 \mathrm{mg} \mathrm{SO}_{4} \mathrm{~L}^{-1}$ ), as these ions were low in atmospheric deposition before the industrial development started in Northern Italy in the 1960s (Schöpp et al., 2003);

- negligible presence of ammonium ion.

The obtained concentrations (Tab. 1; Fig. 3) are close to those reported by Vollenweider (1963), which however could not use major ions concentrations in tributaries and $\mathrm{Na}$ and $\mathrm{Cl}$ in lake concentrations.

The effects of liming (May 1989-June 1990) were immediate and substantial. The remaining ammonium in lake water was completely oxidized (Fig. 3a), producing a slight peak of nitrate (Fig. 3b), and $\mathrm{pH}$ sharply increased, reaching values close to the neutrality (Fig. 2).

The whole set of available data for Lake Orta was used also to describe the long-term trend of dissolved trace metals. Average data through the water column at spring overturn were considered (Fig. 4; Tab. 1).

Copper was mainly responsible for the first dramatic damage to biota in the lake, and $\mathrm{Cu}$ levels were already extremely high by the first half of the 1950s (70-80 $\mu \mathrm{g} \mathrm{L}^{-}$ $\left.{ }^{1}\right)$, and they peaked $110 \mu \mathrm{g} \mathrm{L}^{-1}$ at the end of that decade (Fig. 4a). Concentrations then decreased as $\mathrm{Cu}$ was recovered for economic reasons by the industry through reduction with metallic iron (Monti, 1930), with the effect of increasing levels of iron in the industrial effluents. In the 1970s the effluents of the plating factories produced high values of $\mathrm{Zn}, \mathrm{Cr}$ and $\mathrm{Ni}$ (Fig. 4; Tab. 1), while $\mathrm{Al}$ values increased because of the solubilisation of alumino-silicates in the very acidic lake water. The pivotal factor driving trace metal change in Lake Orta was the ammonium in-lake oxidation (Vollenveider, 1963): this process caused $\mathrm{pH}$ to drop, nitrate to accumulate and the ionic form of metals to persist dissolved in lake water. The $\mathrm{pH}$ recovery induced by the liming treatment, coupled with the reduction of external loads, establish the condition for toxic metal to precipitate. As a whole, the metal-polluted condition of the lake water lasted for over three decades, inhibiting the activities and recovery of biota (Manca and Comoli, 1995; Cattaneo et al., 1998; Ruggiu et al., 1998; Piscia et al., 2012).

The increase in $\mathrm{pH}$ following liming produced a sharp decrease of $\mathrm{Zn}, \mathrm{Fe}, \mathrm{Cr}$ and $\mathrm{Al}$, while the decline of $\mathrm{Cu}, \mathrm{Ni}$ and $\mathrm{Mn}$ was slower (Fig. 4). This situation permitted a gradual biological recovery, with the reappearance of planktonic species, which have been excluded by the presence of toxic metals (Morabito et al., 2001; Bonacina and Pasteris, 2001).

Particularly important, also in relation to the effect on the benthic fauna, is the quality of lake sediments: recent studies revealed the presence of toxic residues in the top layer of Lake Orta sediments, which could potentially act as a source of metals to the water column (Baudo and Beltrami, 2001). The presence of trace metals in the sedi- 
ments also prevent a full recolonization by macrobenthic organisms (Nocentini et al., 2001).

\section{The recent phase of recovery}

Water chemistry variables related to acidification changed drastically in Lake Orta in the years immediately after the liming (Fig. 5). Even before liming, TA values were positive in the lake during the summer months $(0.03$ $0.07 \mathrm{meq} \mathrm{L}^{-1}$ ), and epilimnetic $\mathrm{pH}$ was between 6.0 and 7.0 , an effect of the tributaries' buffering waters, with their TA of between $0.3-0.4$ meq $\mathrm{L}^{-1}$.

This water layer may have been viable for some plankton species at that time, even if during winter overturn the

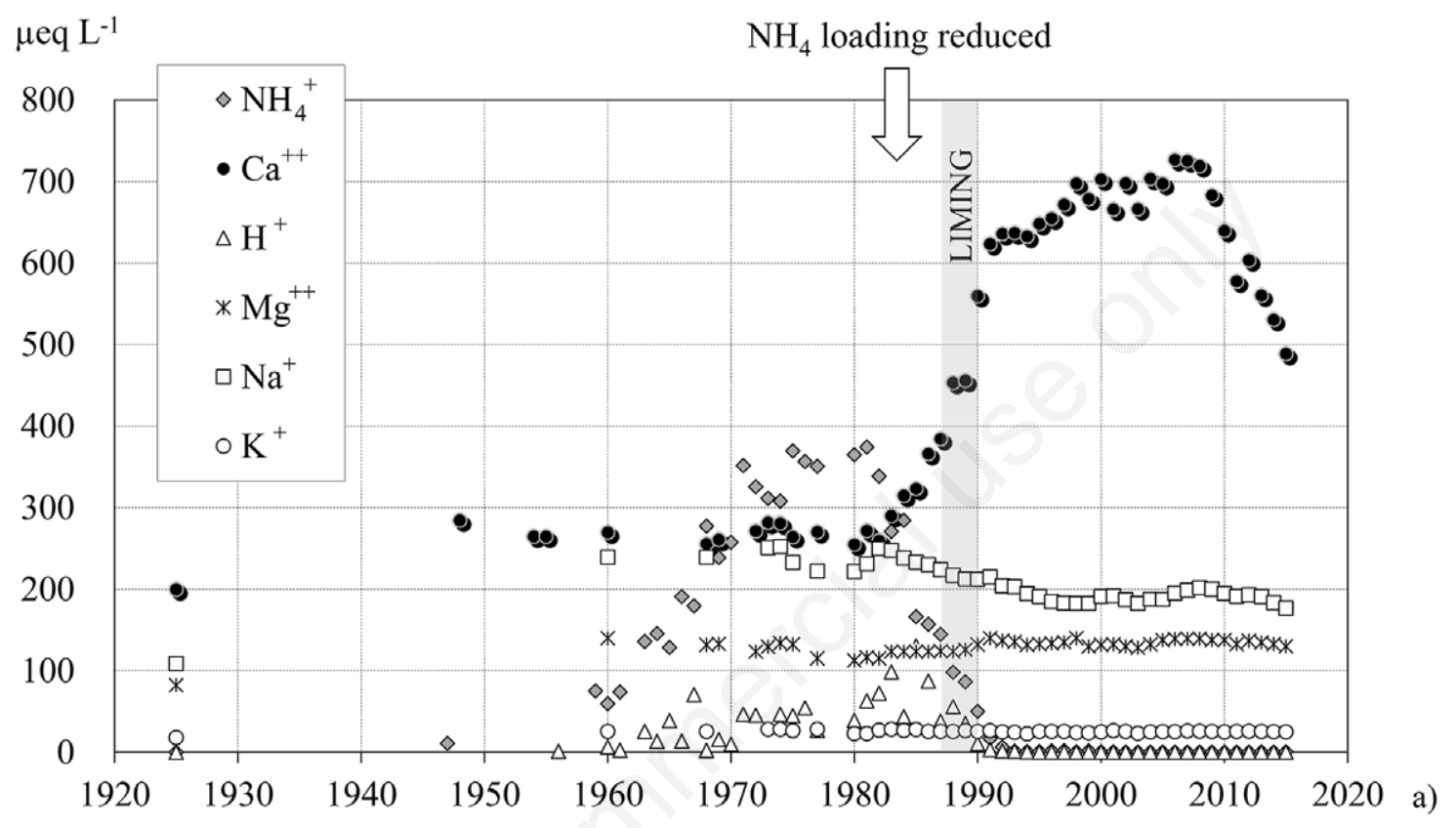

$\mu \mathrm{eq} \mathrm{L}^{-1}$

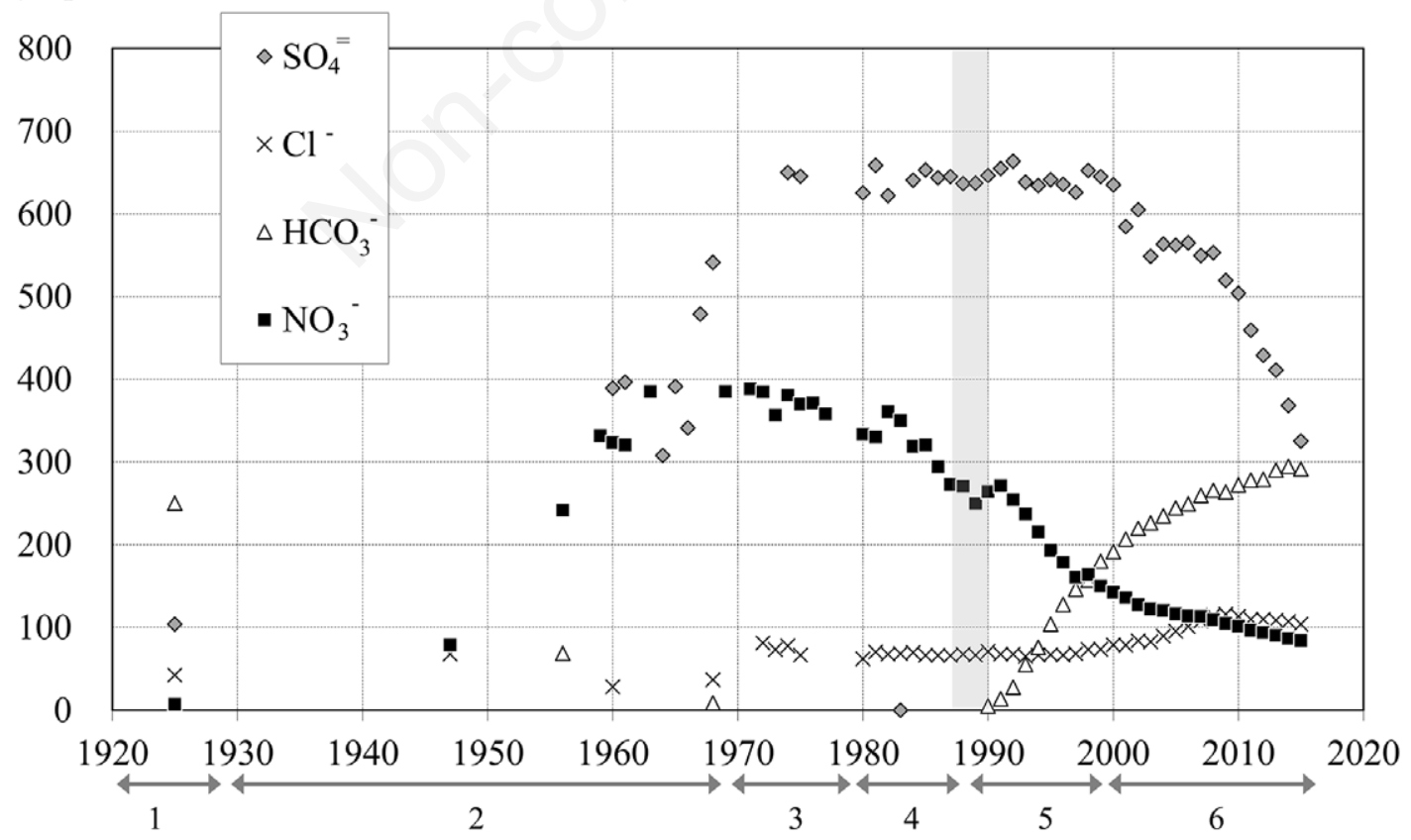

Fig. 3. Long-term trend of cations (a) and anions (b) in Lake Orta, compared with evaluated pre-pollution values (before 1928). The grey area highlights liming period. Periods from 1 to 6 as in Tab. 1. 
whole water mass re-acidified (Pizzolon et al., 1992; Morabito and Curradi, 1997; Morabito, 1999). This improvement in $\mathrm{pH}$ was attributable to the decrease of industrial ammonium discharge in 1981 (Bonacina et al., 1986).

Liming affected the whole mass of water. The most immediate and important result was the buffering of the natural acidity of the lake, and of the acidity produced by the oxidation of the remaining ammonium, but $\mathrm{pH}$ of the whole water mass, while being high in epilimnion during the addition of calcium carbonate, remained initially below 6.0 , and alkalinity was absent (Fig. $5 \mathrm{a}, \mathrm{b}$ ). The input of bicarbonate from the tributaries lead to the establishment of a stable alkalinity pool in the whole mass of water two years after liming (Calderoni et al., 1994). The recovery of alkalinity was of course faster in the epilimnion, during the thermal stratification, and it fostered of intense activity by phytoplankton, proven by epilimnetic peaks of $\mathrm{pH}$ and oxygen (Fig. 5a, c, Morabito and Curradi, 1997; Morabito, 1999). In the following years TA gradually increased, reaching values of between $0.25-0.30 \mathrm{meq} \mathrm{L}^{-1}$, close to the natural levels of the lake (Fig. 5b). These values are even higher than those forecasted by the model used to plan the liming (0.2 meq L ${ }^{-1}$, Mosello et al., 1991). It must be considered that this model was based on budget data for 19841987; atmospheric deposition of acidity has decreased substantially in the watershed of Lake Orta since that time (Rogora et al., 2006b).

An input-output budget for alkalinity was calculated on annual basis for the period 1984-2010 (Fig. 6). The budget showed a clear discrepancy between the total input from inflowing waters and the output in the period 1980s and 1990s; after the liming the values progressively converged and reached a steady state condition in the last few years. The in-lake depletion of alkalinity due to the acidification process was progressively reduced, and the alkalinity of the Niguglia River outflow increased from

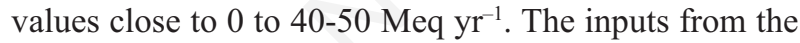
catchment varied between 30 and $50 \mathrm{Meq} \mathrm{yr}^{-1}$, and gradually rebuilt an alkalinity pool in the lake.

Hypolimnetic oxygen concentration were quite low during thermal stratification, an effect of the oxidation of the ammonium in the lake (Fig. 5c). The hypolimnion was only partially re-oxygenated during winter overturn. This hypolimnetic oxygen deficit gradually decreased in the three years following the liming and, since 1994, the concentration stabilized at values close to $9.0 \mathrm{mg} \mathrm{L}^{-1}$, a value expected given lake temperature, the moderate productivity of the lake (Pizzolon et al., 1992) and the small percentage of volume of the productive layer $(0-10 \mathrm{~m})$, equal to about $17 \%$ of the total lake volume. Epilimnetic oxygen concentrations were high in spring and summer, likely related to episodes of phytoplankton productivity, highlighted also in the $\mathrm{pH}$. Peak values of both oxygen and $\mathrm{pH}$ can not be compared in the periods previous and after
2001, because of the different sampling frequency, monthly and quarterly, respectively.

Nitrate concentrations (Fig. 2; Fig. 5d) peaked at 4.2 $\mathrm{mg} \mathrm{N} \mathrm{L}{ }^{-1}$ in the whole water mass soon after the liming; thereafter concentrations decreased steadily due to the dilution from the tributary waters, with their much lower concentrations (1.3-2.8 $\left.\mathrm{mg} \mathrm{L}^{-1}\right)$. At present, in-lake values are close to $1 \mathrm{mg} \mathrm{N} \mathrm{L}^{-1}$, not far from those of the nearby Lake Maggiore, whose nitrogen levels are currently controlled largely by atmospheric input of nitrogen, both as ammonium and nitrate (Rogora et al., 2006a). The epilimnetic nitrate concentration in Lake
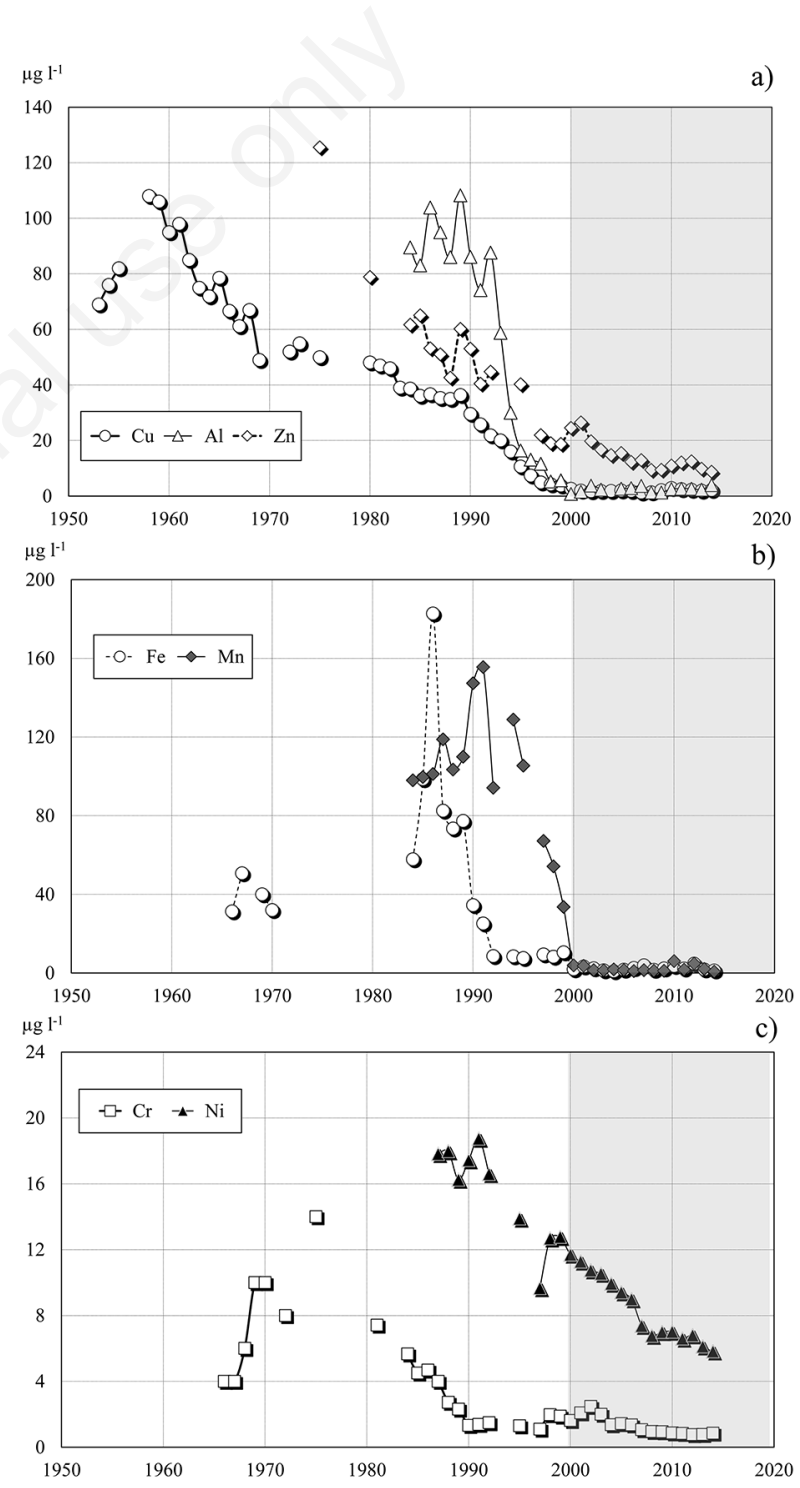

Fig. 4. Long-term trends of the main trace metals in the water of Lake Orta. Average values along the water column at spring overturn. The grey area highlights the most recent monitoring period (a) $\mathrm{Cu}, \mathrm{Al}, \mathrm{Zn}$; b) $\mathrm{Fe}, \mathrm{Mn}$; c) $\mathrm{Cr}$, Ni. 
Orta has regular seasonal variations, with minima in the spring and summer, due to biological activity and to the more intense effect of the tributary waters during the period of thermal stratification.

\section{Change in major ion concentrations}

Beside those chemical variables strongly involved in the acidification and recovery processes, other chemical parameters were regularly monitored in Lake Orta, to assess the ionic balance of lake water. Major cations (calcium, magnesium, sodium and potassium) and anions (sulphate and chloride) were determined on each lake sample, as well as on the monthly samples taken from the tributaries.

Calcium concentrations initially reflected the liming intervention. Epilimnetic levels were very high following the liming (Fig. 7a), in strict agreement with the increase of total alkalinity. Ca levels increased by about $2 \mathrm{mg} \mathrm{L}^{-1}$ in the whole water mass, an increase in good agreement with the amount of lime used (14 $800 \mathrm{t}$ expressed as pure $\mathrm{CaCO}_{3}$; Calderoni and Tartari, 2000). Ca levels remained between 13 and $14 \mathrm{mg} \mathrm{L}^{-1}$ for two decades after liming, reflecting amounts discharged from the industrial efflu- ents. However, in 2009, Ca levels began to fall quite rapidly, reaching $9-10 \mathrm{mg} \mathrm{L}^{-1}$ by 2014 . Levels of both calcium and sulphate decreased after 2009, from about 13 and $30 \mathrm{mg} \mathrm{L}^{-1}$ in 2000-2008 to the recent values of 10 and $18 \mathrm{mg} \mathrm{L}^{-1}$, respectively (Fig. 7a, b). The 1991 epilimnetic Ca peak, related to an equivalent peak of alkalinity (Fig. $5 b$ ), was clearly due to the input of $\mathrm{CaCO}_{3}$ during liming, and this increase was reflected in slight increases in 1992 and 1993 over the whole water column. Ca concentrations started to decrease in 2009, but the sulphate decrease had begun a decade earlier, in 1999, and the rate of decrease steepened in 2009, after the rayon factory closed (Fig. 7b).

Concentrations of sodium and chloride have also decreased since 2009, from 4.5-4.6 to 4.0-4.1 $\mathrm{mg} \mathrm{L}^{-1}$ and from 4.4-4.5 to 3.6-3.7 $\mathrm{mg} \mathrm{L}^{-1}$, respectively (Fig. $7 \mathrm{c}, \mathrm{d}$ ). In earlier years, sodium concentrations had first decreased (1990-1999), then increased (2000-2008). The Cl pattern is different, its concentrations increasing during the period up to 2009 .

The varying trends of the four ions after 2009 are probably due to the cessation of industrial activity at the Bemberg factory, whose effluent contributed substantially to the lake total loads. The differences between epi- and hypolimnetic concentrations are likely due to the effect of

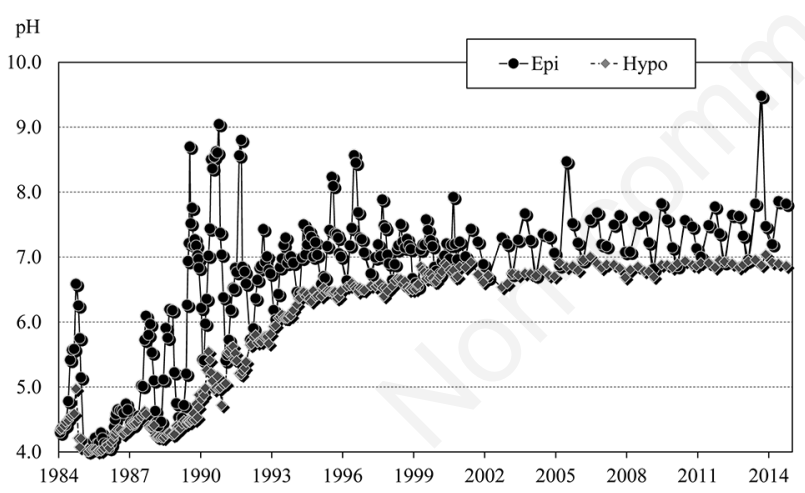

a)

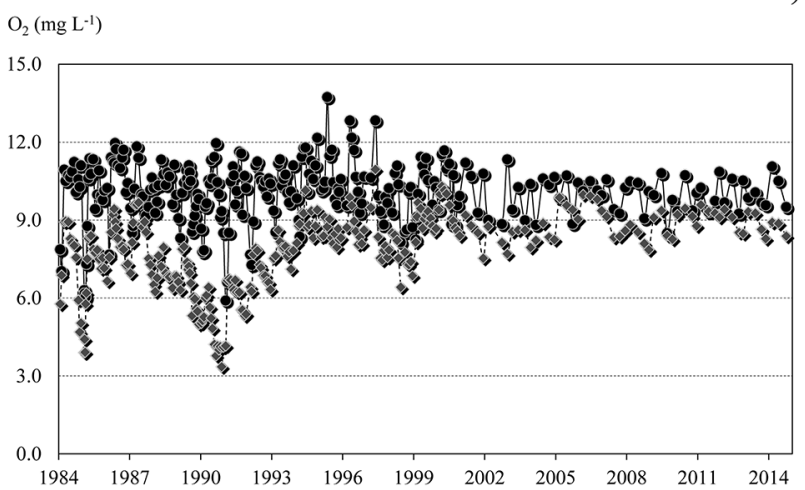

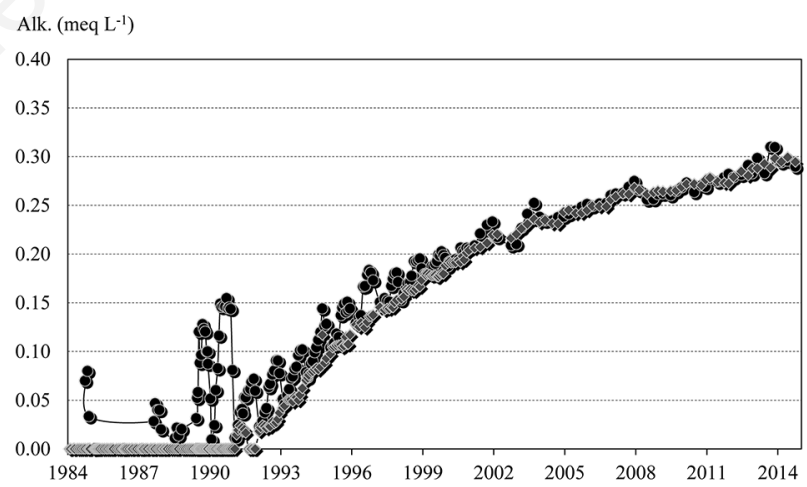

b)

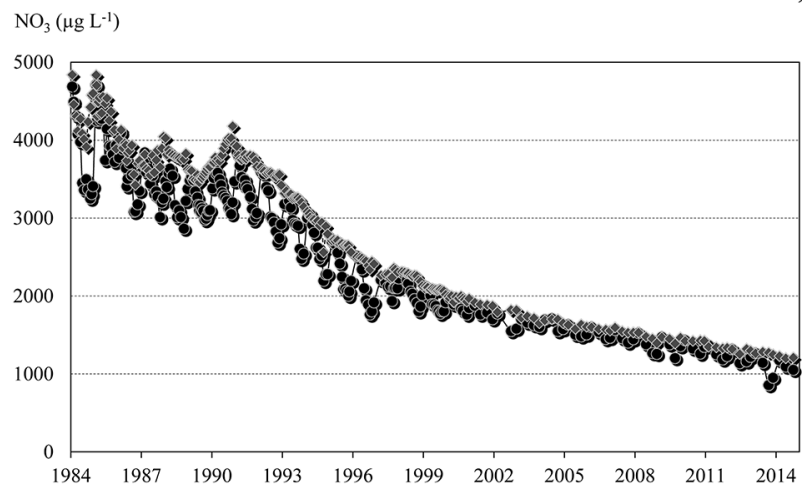

Fig. 5. Trend of monthly (1990-2000) and quarterly (since 2001) values of pH (a), alkalinity (b), dissolved oxygen (c) and nitrate (d) in the epilimnion and hypolimnion of Lake Orta. 
tributary inflows, with mean ion concentrations lower than the lake water.

\section{Change in trace metal concentrations}

All metals responded to the liming of the lake, but at different rates. Concentrations at winter overturn of $\mathrm{Fe}$, $\mathrm{Mn}, \mathrm{Al}$ and $\mathrm{Zn}$ fell quite rapidly, while $\mathrm{Ni}$ and $\mathrm{Cr}$ levels decreased more slowly over time. The same patterns were evident in differences among metals between the epi- and hypolimnetic concentrations, which were pronounced even before the liming (Fig. 8 a,b), and whose total concentrations fell after the liming. In the case of $\mathrm{Cr}$ and $\mathrm{Ni}$, there were no differences between epi- and hypolimnion (Fig. $8 \mathrm{c}$,d), and only Ni levels declined in the upper water layers in the years following liming. Explaining these results is not easy, as the inherent chemistry of the different metals, their dilution from tributary waters, and the potential persistence of sources of pollution must all be considered. Metals in fact were derived mainly from plating factories in the southern part of the watershed, whose activities are at all separated from the rayon factory, primary source of copper and ammonium (Bonacina et al., 1986; Mosello et al., 1989).

To determine if the present situation of metal levels in Lake Orta is similar to other subalpine lakes in the region, we compared trace metal data from Lake Orta in 2012-
2013 with those of the near lakes Mergozzo and Maggiore (Fig. 9). The dominant metal in Lake Orta water was Zn, with values ranging between 4.3 and $10 \mu \mathrm{g} \mathrm{L}^{-1}$, followed by Ni (2.0-6.4 $\left.\mu \mathrm{g} \mathrm{L}^{-1}\right), \mathrm{Al}$ (about $\left.2 \mu \mathrm{g} \mathrm{L}^{-1}\right), \mathrm{Cu}(0.9-1.9$ $\left.\mu \mathrm{g} \mathrm{L}^{-1}\right), \mathrm{Fe}\left(0.7-2.8 \mu \mathrm{g} \mathrm{L}^{-1}\right)$ and $\mathrm{Cr}\left(0.2-0.9 \mu \mathrm{g} \mathrm{L}^{-1}\right)$. As a whole, concentrations did not vary over the seasons; levels in Lake Orta were slightly higher in winter (December) and spring (March), but these differences were statistically significant only for $\mathrm{Cu}, \mathrm{Fe}$ and $\mathrm{Zn}$ (KruskallWallis Test; $\mathrm{P}<0.01$ ). Concentrations of $\mathrm{Cr}$, $\mathrm{Ni}$ and $\mathrm{Zn}$ were slightly higher in Lake Orta than in the other lakes. Using a Wilcoxon paired test, concentrations of $\mathrm{Cr}$, $\mathrm{Ni}$ and $\mathrm{Zn}$ were significantly higher in Lake Orta $(\mathrm{P}<0.001$ for $\mathrm{Cr}$ and $\mathrm{Ni}, \mathrm{P}<0.05$ for $\mathrm{Zn}$ ) than in Lake Maggiore, while values did not differ for $\mathrm{Fe}, \mathrm{Mn}$ and $\mathrm{Cu}$. Levels of $\mathrm{Al}$ were higher in Lake Maggiore $(\mathrm{P}<0.001)$.

Only three of the considered trace metals are included in the list of the priority substance for which Environmental Quality Standard (EQS) are set by the European legislation (Annex II of Directive 2008/105/EC): annual average dissolved concentrations of $\mathrm{Ni}, \mathrm{Pb}$ and $\mathrm{Cd}$ must be below $20 \mu \mathrm{g} \mathrm{L}^{-1}, 7.2 \mu \mathrm{g} \mathrm{L}^{-1}$ and $0.08 \mu \mathrm{g} \mathrm{L}^{-1}$, respectively. Current concentrations in Lake Orta are fairly below these limits. However, beside the dissolved form, concentrations and chemical speciation of trace metals in other lake compartments (e.g., particulate matter, sediments) should be also taken into account.

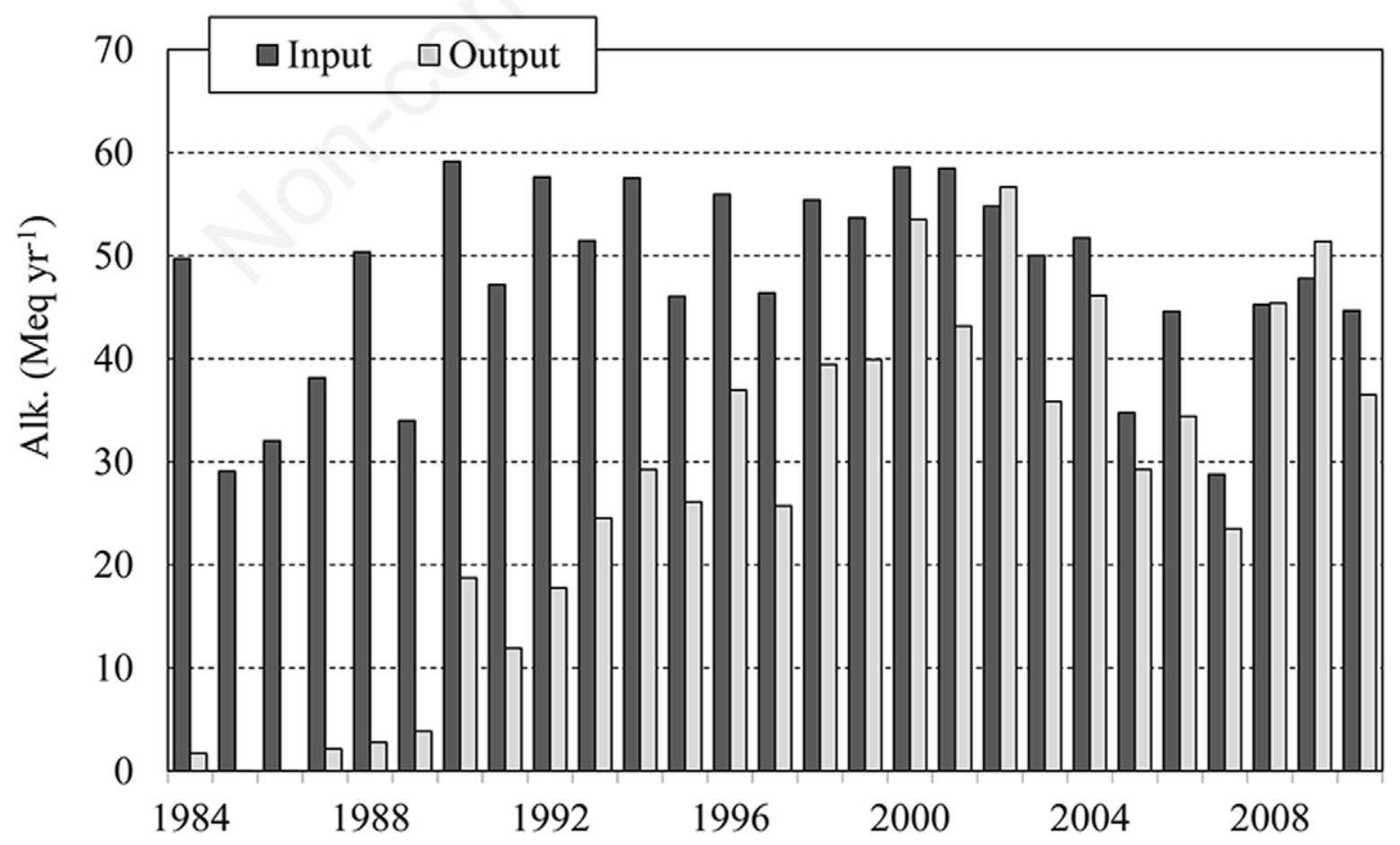

Fig. 6. Annual input of alkalinity in Lake Orta from the main tributaries compared with the output through the Niguglia River. 


\section{Trophic status and phosphorus trends}

Concentration of phosphorus was very low in Lake Orta, both before and after the onset of industrial pollution. Reactive phosphorus levels in most cases were below or very close to the detection limit of the method used, so will not be considered. On the basis of the total phosphorus (TP) values measured at spring overturn (4 $\mu \mathrm{g} \mathrm{P} \mathrm{L}^{-1}$ ), Lake Orta can be classified as oligotrophic or ultra oligotrophic. Slightly higher values (6-7 $\left.\mu \mathrm{g} \mathrm{P} \mathrm{L} \mathrm{L}^{-1}\right)$ were detected in the 1980s and 1990s, however still in the range of oligotrophy and very far from those measured, for instance, in the nearby Lake Maggiore in that period (30-35 $\mu \mathrm{g} \mathrm{P} \mathrm{L}^{-1}$; Salmaso et al., 2003).

There were some vertical differences of TP in Lake Orta. Epilimnetic values were slightly higher in the early 1980s, when 12-14 $\mu \mathrm{g} \mathrm{P} \mathrm{L}{ }^{-1}$ were measured on occasion (Fig. 10). Since the 1990s, values rarely exceeded $10 \mu \mathrm{g} P$ $\mathrm{L}^{-1}$. Concentrations in the hypolimnion varied between 3 and $7 \mu \mathrm{g} \mathrm{P} \mathrm{L}^{-1}$, with a tendency towards even lower values in recent years (3-4 $\left.\mu \mathrm{g} \mathrm{P} \mathrm{L}^{-1}\right)$. These very low concentrations of phosphorus can be explained by the limited input of this element from the inflowing waters. Nutrients have been monitored on a monthly basis in the main tributaries of the lake from 1984-2010: phosphorus concentrations were highly variable, from $15-20 \mu \mathrm{g} \mathrm{P} \mathrm{L}^{-1}$ (mean values in 2000-2010) to $100-150 \mu \mathrm{g} \mathrm{P} \mathrm{L}^{-1}$ in the most polluted rivers, Lagna and Fiumetta. However, both these two rivers were subject to diversion of urban discharge, starting in 2001 and 2004, respectively. This intervention led to a sharp decrease of phosphorus concentrations in the inflowing waters to Lake Orta. The annual phosphorus load from the tributaries, estimated as explained in the method section, decreased from 6-10 $\mathrm{t} \mathrm{P} \mathrm{yr}^{-1}$ before 2004 to values close or below $2 \mathrm{t}$ $\mathrm{P} \mathrm{yr}^{-1}$ in very recent years (Fig. 11). These values underestimate the effective input to the lake, because they do not include the area not drained by the tributaries and the coastal area. However, even assuming a similar contribution of phosphorus from these parts of the catchment, the phosphorus load to Lake Orta is very low and consistent with the actual trophic condition of the lake.

Phosphorus levels have been constantly low in the lake, since the monitoring started: average concentrations measured at spring overturn were between 4 and $8 \mu \mathrm{g} \mathrm{P}$ $\mathrm{L}^{-1}$ during the various pollution phases (Tab. 1), despite the higher load from the watershed affecting the lake in the 1980s (Fig. 11). It can be hypothesized that co-precipitation of phosphorus with metals contributed to maintain

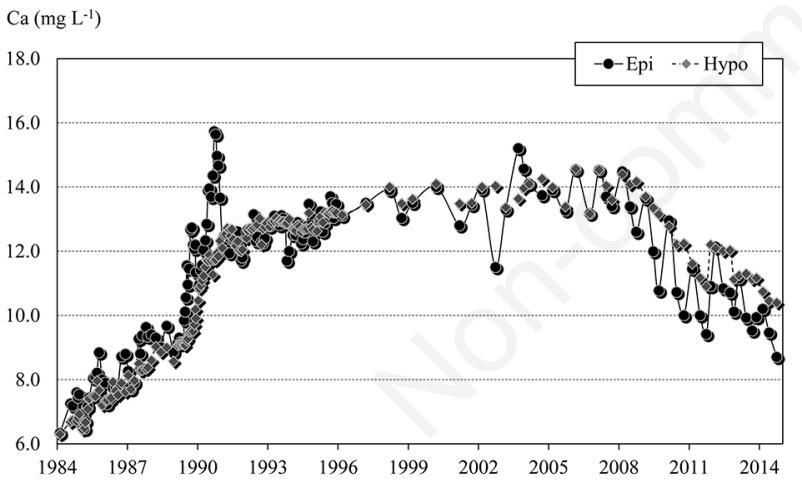

$\mathrm{SO}_{4}\left(\mathrm{mg} \mathrm{L}^{-1}\right)$

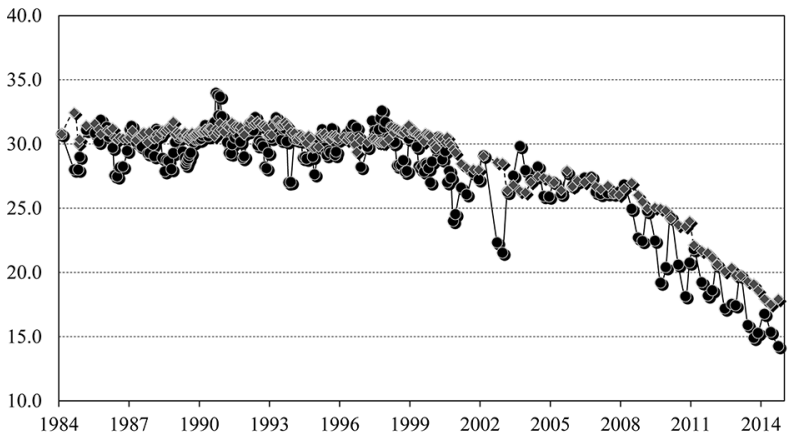

a)

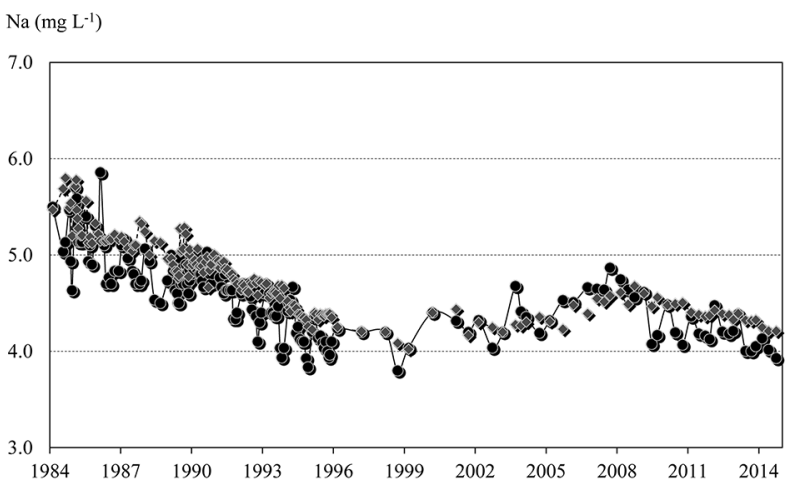

b)

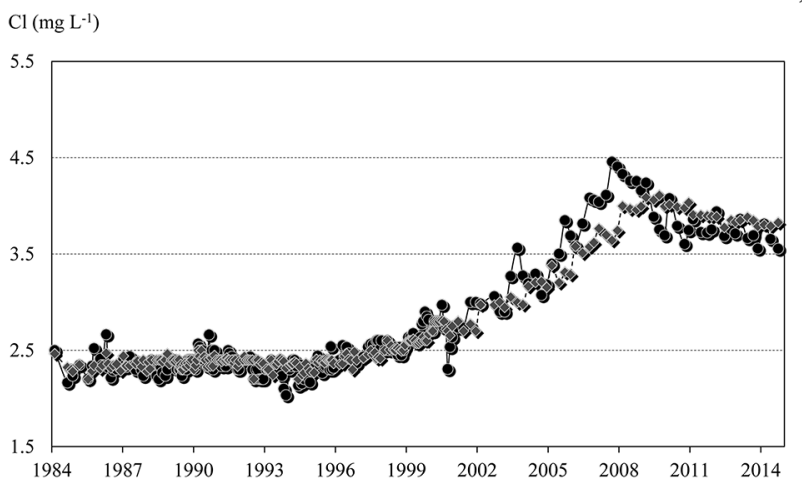

Fig. 7. Trend of monthly (1990-2000) and quarterly (since 2001) values of calcium (a), sulphate (b), sodium (c) and chloride (d) in the epilimnion and hypolimnion of Lake Orta. 

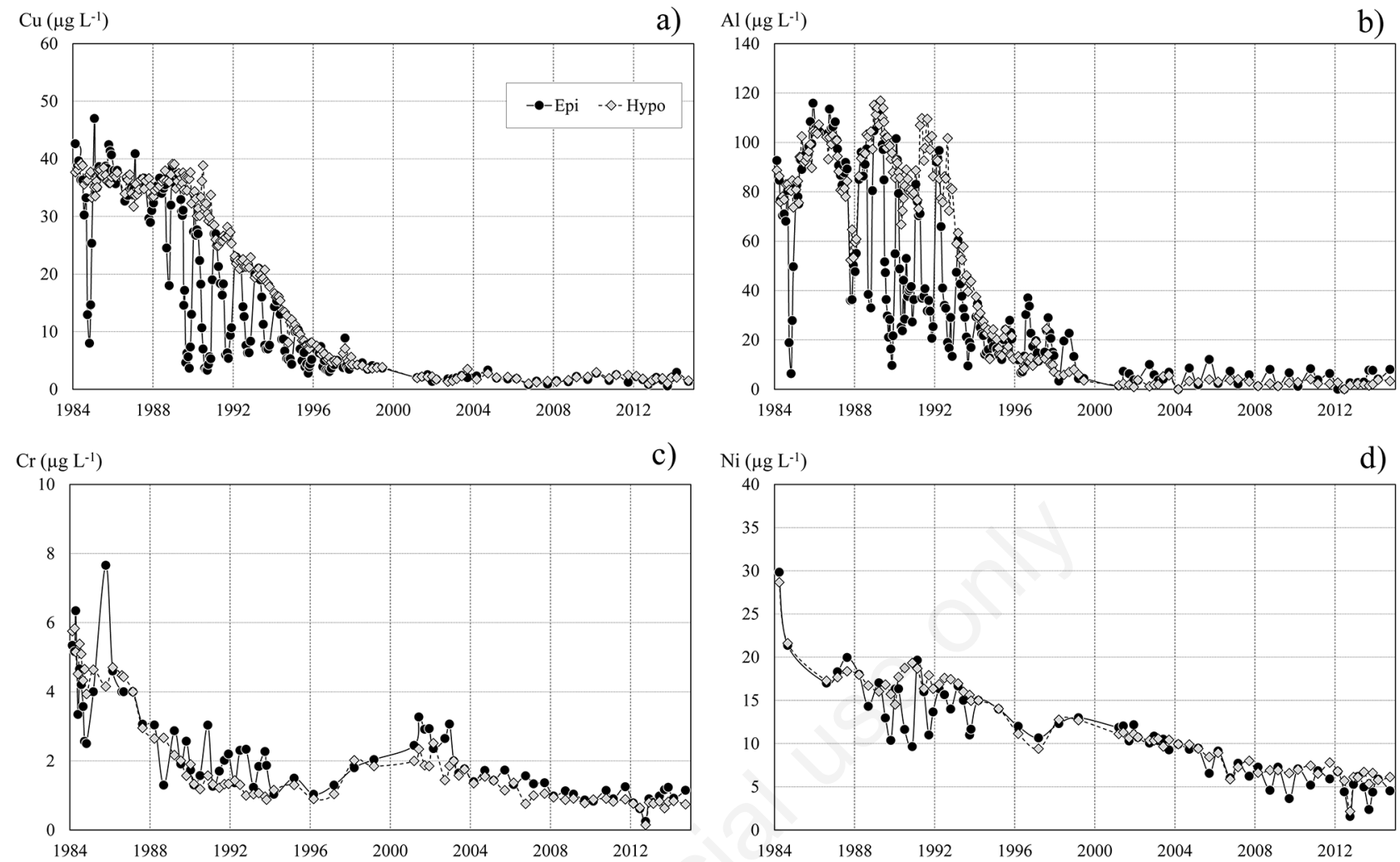

c) $\quad \mathrm{Ni}\left(\mu \mathrm{g} \mathrm{L} \mathrm{L}^{-1}\right)$

d)

Fig. 8. Trend of monthly (until 2000) and seasonal (2001-2014) concentrations of selected heavy metals in the epilimnetic and hypolimnetic waters of Lake Orta.
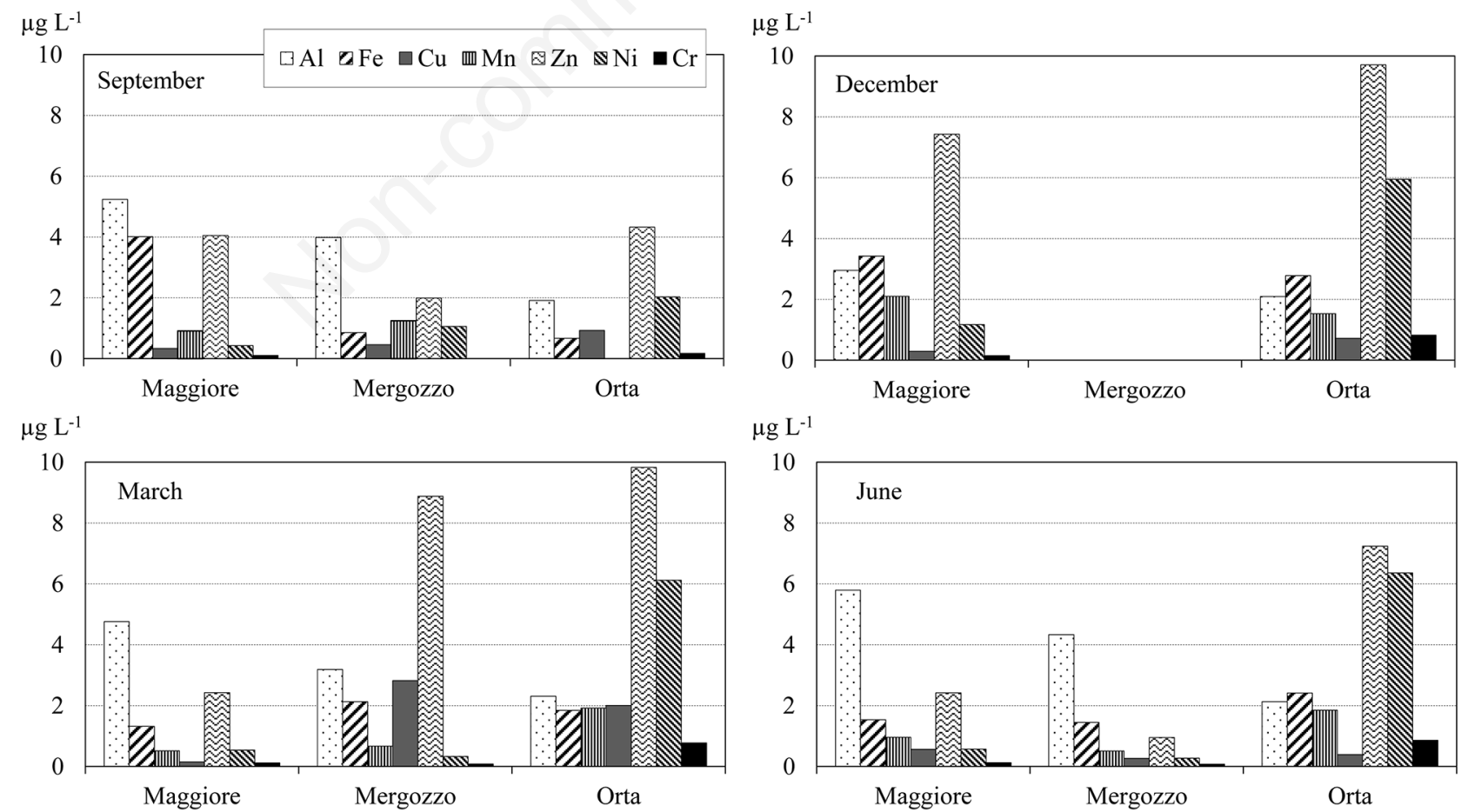

$\mu \mathrm{g} \mathrm{L}^{-1}$
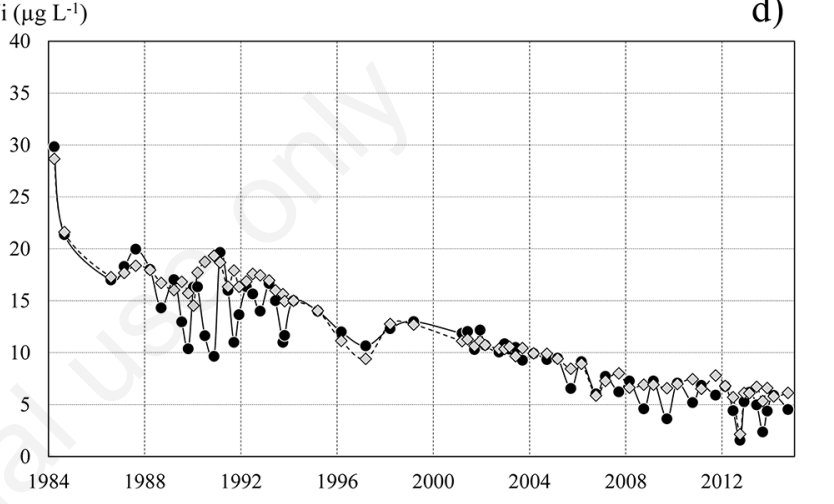

\section{政}


low phosphorus levels in the lake during the acidification period and in the first phase of recovery: in particular, increased metal precipitation, especially of $\mathrm{Al}, \mathrm{Fe}$ and $\mathrm{Mn}$ after the liming may have enhanced phosphorus sedimentation and reduced internal phosphorus cycling ( $\mathrm{Hu}$ and Huser, 2014).

In contrast to phosphorus, silica concentrations did change markedly in the recovery period (Fig. 10), as an effect of the recolonization of the lake by diatom species. Sil- ica had been steadily above $4.0 \mathrm{mg} \mathrm{Si} \mathrm{L}^{-1}$ in the $1970 \mathrm{~s}$ and 1980s (Tab. 1); starting from the 1990s, concentrations gradually decreased, as an effect of the biological uptake, reaching values around $2.5 \mathrm{mg} \mathrm{Si} \mathrm{L}{ }^{-1}$ in recent years. The reappearance of diatoms in the lake is verified from the phytoplankton studies (Morabito et al., 2001) and supported by the evident seasonality of silica concentrations in surface water: minima of 1.4-1.6 $\mathrm{mg} \mathrm{Si} \mathrm{L}^{-1}$ were reached in some cases in summer months, and in September 2013


Fig. 10. Trends of total phosphorus (left panel) and reactive silica (right panel) concentrations in Lake Orta in 1984-2014; average values in the epilimnetic and hypolimnetic waters.

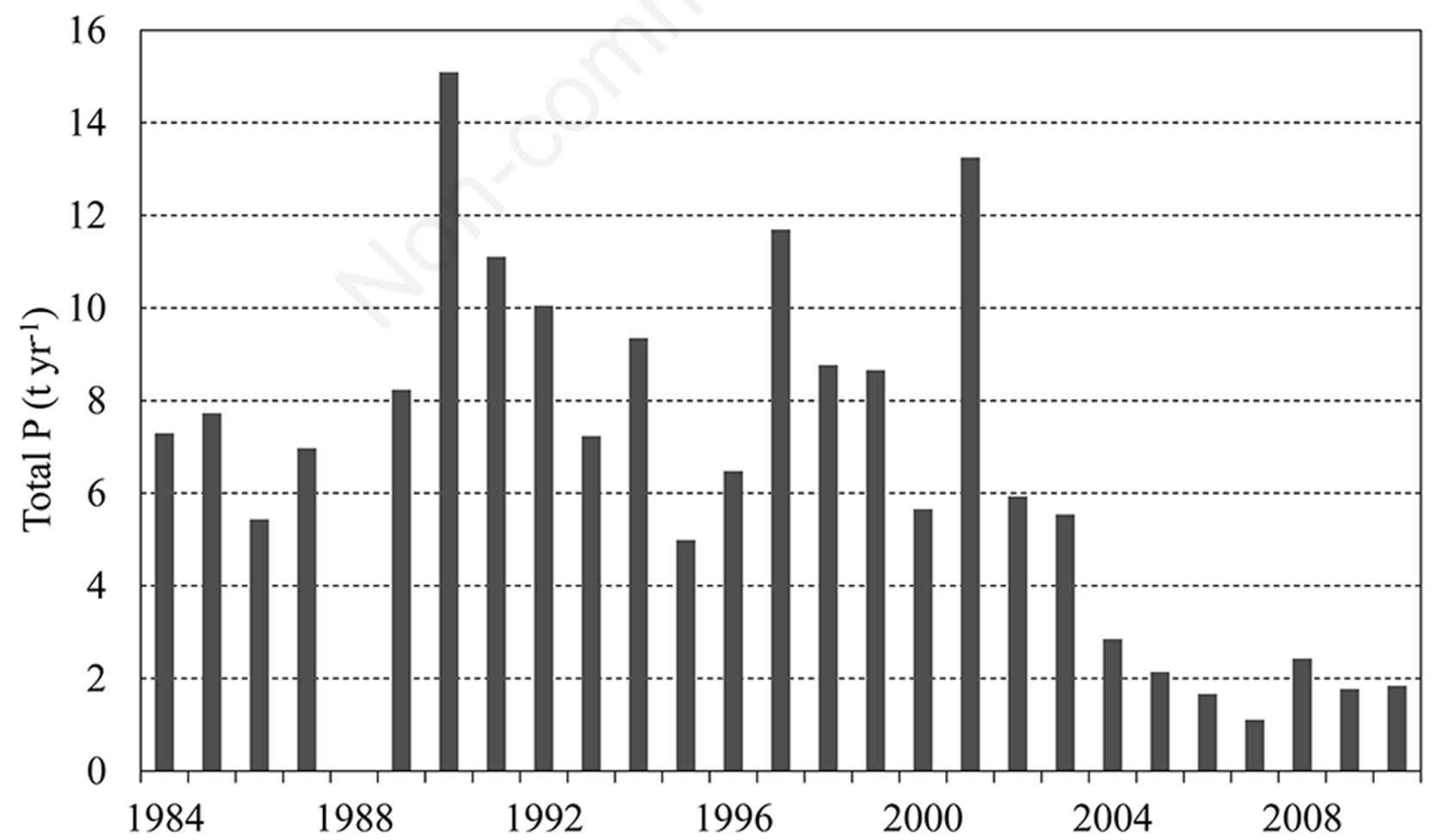

Fig. 11. Annual load of total phosphorus to Lake Orta from the main tributaries in the period 1984-2010. Loads calculated from monthly concentrations in river water and estimated discharge (see Methods section for the details). 
the pool of silica was almost totally depleted by a diatom bloom (Morabito, personal communication).

\section{CONCLUSIONS}

The acid-base status of Lake Orta has completely recovered to conditions modelled for the pre-pollution period. Ammonium levels are now very low, in the range of those observed in the other subalpine oligotrophic lakes, while nitrate is still decreasing. Trace metals sharply decreased since the 1980s in response to the reduction of the external load and the increase of $\mathrm{pH}$ of the water, due to the restoration of a permanent reserve of alkalinity in the waters. Present concentrations of $\mathrm{Fe}, \mathrm{Mn}, \mathrm{Al}$ and $\mathrm{Cu}$ are low, and not markedly different from those of the nearby lakes Maggiore and Mergozzo. Dissolved concentrations of $\mathrm{Ni}, \mathrm{Cd}$ and $\mathrm{Pb}$ are fairly below the environmental quality standards set at a European level for inland waters (Directive 2008/105/EC). Hypolimnetic anoxia has also been eliminated which permits the survival of hypolimnetic colonists. On the other hand, the slower decrease of $\mathrm{Ni}$ and the presence of $\mathrm{Cr}$, although at low levels, still might pose a threat for biota, as discussed in Piscia et al. (2016), also in relation to other chemical variables (e.g., $\mathrm{Ca}, \mathrm{Na}$ ). Solubilization of trace metals from the sediments must be also taken into account, particularly in relation with the oxygen levels in the deeper waters. For this aspect, it became extremely important to control the trophic condition of the waters i.e. the $\mathrm{P}$ loads from the tributaries, to avoid anoxia conditions during the thermal stratification. To this purpose, monitoring of catchment loads trough the main tributaries, interrupted in 2010, should be restored. The chemical monitoring of the lake need to be maintained, at least on a seasonal basis, to assess not only the lake response to the treatment measures, but also to new emerging issues.

The relevance of the lake trophy to maintain the good chemical quality of lake water is well known, and therefore we need to emphasize the importance of initiating and maintaining a detailed study of biological components of the lake. Only a well equilibrated and stable biological community could assure the full recovery of Lake Orta.

\section{ACKNOWLEDGEMENTS}

We are grateful to Prof. Norman Yan, Dept. Biology York University, for his precious advices and helpful criticism on the manuscript. We are indebted to all the people involved in field work and laboratory analysis, particularly to Alfredo Pranzo, Paola Giacomotti, Arianna Orrù and Ombretta Tornimbeni.

\section{REFERENCES}

Ambrosetti W, Barbanti L, 2002. Temperature, heat content, mixing and stability in Lake Orta: a pluriannual investigation. J. Limnol. 60 60-68.
Baldi E, 1949. Il Lago d'Orta, suo declino biologico e condizioni attuali. Mem. Ist. Ital. Idrobiol. 5:145-188.

Baudo R, Amantini L, Bo F, Cenci R, Hannaert P, Lattanzio A, Marengo G, Muntau H, 1989. Spatial distribution patterns of metals in the surface sediments of Lake Orta (Italy). Sci. Total Environ. 87/88:117-128.

Baudo R, Beltrami M, 2001. Chemical composition of Lake Orta sediments. J. Limnol. 60:213-236.

Bonacina C, 2001. Lake Orta: the undermining of an ecosystem. J. Limnol. 60:53-59.

Bonacina C, Bonomi G, Barbanti L, Mosello R, Ruggiu D, 1988. Recovery of an industrially acidified, ammonium and heavy metals polluted lake (Lake Orta, N. Italy), due to the adoption of treatment plants. Verh. Intern. Ver. Limnol. 23:35-544.

Bonacina C, Bonomi G, Calderoni A, Mosello R, 1987. [Evoluzione recente dell'inquinamento del Lago d'Orta e proposta di un intervento per il suo recupero].[Article in Italian]. Documenta Ist. Ital. Idrobiol. 14:197-213.

Bonacina C, Bonomi G, Mosello R, 1986. Notes on the present recovery of Lake Orta: an acid, industrially polluted, deep lake in North Italy. Mem. Ist. Ital. Idrobiol. 44:97-115.

Bonacina C, Bonomi G, Ruggiu D, 1973. Reduction of the industrial pollution of Lake Orta (N. Italy): an attempt to evaluate its consequences. Mem. Ist. Ital. Idrobiol. 30:149-168.

Bonacina C, Pasteris A, 2001. Zooplankton of Lake Orta after liming: an eleven years study. J. Limnol. 60:101-109.

Calderoni A, de Bernardi R, Mosello R, 1994. Recovery of Lago d'Orta by liming. Verh. Intern. Ver. Limnol. 25:2016-2020.

Calderoni A, Mosello R, Quirci A, 1991. Chemical response of Lake Orta (Northern Italy) to liming. Arch. Hydrobiol. 122:421-439.

Calderoni A, Mosello R, Ruggiu D, 1992. Sixty years of limnology on Lago d'Orta: a case history of recovery from heavy pollution. In: P. Guilizzoni, G. Tartari and G. Giussani (eds.), Limnology in Italy. Mem. Ist. Ital. Idrobiol. 50:201-224.

Calderoni A, Tartari GA, 2000. Evolution of the water chemistry of Lake Orta after liming. J. Limnol. 60:69-78.

Cattaneo A, Asioli A, Comoli P, Manca M, 1998. Organisms response in a chronically polluted lake supports hypothesized link between stress and size. Limnol. Oceanogr. 43:1938-1943.

de Bernardi R, Calderoni A, Mosello R, 1996. Environmental problems in Italian lakes, and lakes Maggiore and Orta as successful examples of correct management leading to restoration. Verh. int. Ver. Limnol. 26: 123-138.

$\mathrm{Hu}$ Q, Huser BJ, 2014. Anthropogenic oligotrophication via liming: long-term phosphorus trends in acidified, limed, and neutral reference lakes in Sweden. Ambio 43(s1):104-112.

Manca M, Comoli P, 1995. Temporal variations of fossil Cladocera in the sediments of Lake Orta (N. Italy) over the last 400 years. J. Paleolimnol. 14:113-122.

Monti R, 1930. La graduale estinzione della vita nel limnobio del Lago d'Orta. Rend. Ist. Lomb. Sc. Lett. 63:3-22.

Monti R, 1929. Limnologia comparata dei laghi insubrici. Verh. Intern. Verein. Limnol. 4:462-497.

Morabito G, 1999. Six years (1992-1997) evolution of phytoplankton communities in Lake Orta (N. Italy) after the recovery by liming. Proc. 8th International Conference on the Conservation and management of Lakes. Copenhagen, Danmark.

Morabito G, 2016. Phytoplankton assemblages in Lake Orta: what functional structure could tell us about the recovery of 
the largest acidic lake in the world. J. Limnol. 75(s2):142152.

Morabito G, Curradi M, 1997. Phytoplankton community structure of a deep subalpine Italian lake (Lake Orta, N. Italy) four years after the recovery from acidification by liming. Int. Rev. Ges. Hydrobiol. 82:487-506.

Morabito G, Ruggiu D, Panzani P, 2001. Trends of phytoplankton characteristics and their communities in pre- and postliming time in Lake Orta (1984-1998). J. Limnol. 60:91-100.

Mosello R, Calderoni A, de Bernardi R, 1991. Mass budget as a tool for predicting the response to liming of the acidified, ammonium polluted subalpine Italian lake (Lake Orta). Verh. Intern. Ver. Limnol. 24:1044-1048.

Mosello R, Baudo R, Tartari GA, 1986. Metal concentrations in a highly acidic lake: L. Orta, (Northern Italy). Mem. Ist. Ital. Idrobiol. 44:73-96.

Mosello R, Calderoni A, Tartari GA, 1989. pH related variations of trace metal concentrations in L. Orta. Sci. Total Environ. 87/88:255-268.

Nocentini AM, Boggero A, De Margaritis G, Gianatti M, 2001. First phase of macroinvertebrate repopulation of Lake Orta (Buccione Basin) after liming. J. Limnol. 60:110-126.

Picotti M, 1964. [Un decennio di controlli delle condizioni fisico-chimiche delle acque del Lago d'Orta].[Article in Italian]. Boll. Pesca, Piscic. Idrobiol. 19:3-194.

Piscia R, Guilizzoni P, Fontaneto D, Vignati D, Appleby PG, Manca M, 2012. Dynamics of rotifer and cladoceran resting stages during copper pollution and recovery in a subalpine lake. International J. Limnol. 48:151-160.

Piscia R, Yan ND, Manca M, 2016. Mechanisms underlying recovery of zooplankton in Lake Orta after liming. J. Limnol. 75(s2):15-21.

Pizzolon L, Ruggiu D, Morabito G, 1992. Primary production and phytoplankton communities in the acidified Lake Orta
(N. Italy) after the removal of ammonia pollution. Mem. Ist. Ital. Idrobiol. 51:29-52.

Rogora M, Mosello R, Arisci S, Brizzio MC, Barbieri A, Balestrini R, Waldner P, Schmitt M, Stähli M, Thimonier A, Kalina M, Puxbaum H, Nickus U, Ulrich E, Probst A, 2006a. An overview of atmospheric deposition chemistry over the Alps: present status and long-term trends. Hydrobiologia 562:17-40.

Rogora M, Mosello R, Calderoni A, Barbieri A, 2006b. Nitrogen budget of a subalpine lake in North-Western Italy: the role of atmospheric input in the upward trend of nitrogen concentrations. Verh. Internat. Verein. Limnol. 29:2027-2030.

Ruggiu D, Luglié A, Cattaneo A, Panzani P, 1998. Paleoecological evidence for diatom response to metal pollution in Lake Orta (N. Italy). J. Paleolimnol. 20:333-345.

Salmaso, N, Morabito G, Mosello R, Garibaldi L, Simona M, Buzzi F, Ruggiu D, 2003. A synoptic study of phytoplankton in the deep lakes south of the Alps (lakes Garda, Iseo, Como, Lugano and Maggiore). J. Limnol. 62:207-227.

Schöpp W, Posch M, Mylona S, Johansson M, 2003. Long-term development of acid deposition (1880-2030) in sensitive freshwater regions in Europe. Hydrol. Earth Syst. Sci. 7:436-446.

Tartari GA, Marchetto A, Mosello R, 1995. Precision and linearity of inorganic analyses by ion chromatography. J. Chromatogr. 706:21-30.

Tonolli V, Vollenweider RA, 1961. [Rapporto sulle ricerche eseguite sul Lago d'Orta nel periodo dal 1959 al 1961].[Report in Italian]. Pallanza: 18 pp.

Vollenweider RA, 1963. Studi sulla situazione attuale del regime chimico e biologico del Lago d'Orta. Mem. Ist. Ital. Idrobiol. 16:21-125.

Volta P, Yan ND, Gunn JM, 2016. Past, present and future of the fish community of Lake Orta (Italy), one of the world's largest acidified lake. J. Limnol. 75(s2):131-141. 